\title{
Correlation Between Lipid Profiles with Pancreatic $\beta$ - Cell Function in Patients with Type 2 Diabetes Mellitus
}

\author{
Dwi Sarbini ${ }^{1 *}$, Emy Huriyati ${ }^{2}$, Ahmad Hamim Sadewa ${ }^{3}$, \\ Mae Sri Hartati Wahyuningsih ${ }^{4}$
}

\begin{abstract}
${ }^{I}$ Nutrition Department Faculty of Health Science, Universitas Muhammadiyah Surakarta, Central Java, Indonesia ${ }^{2}$ Nutrition Department Faculty of Health Science, Universitas Gadjah Mada, Yogyakarta, Indonesia ${ }^{3}$ Biochemistry Department Faculty of Medical Science Public, Universitas Gadjah Mada, Yogyakarta, Indonesia ${ }^{4}$ Pharmacology and Therapy Department, Herbal Medicine Center, Faculty of Medical Science Public Health and Nursing, Universitas Gadjah Mada, Yogyakarta, Indonesia

*Corresponding author.E-mail:Dwi.Sarbini@ums.ac.id
\end{abstract}

\begin{abstract}
Type 2 Diabetes Mellitus (T2DM) is characterized by 2 times higher blood glucose and lipid profile than nondiabetic people. Several studies indicated that pancreatic $\beta$ cell dysfunction due to dyslipidemia is an independent risk factor T2DM. Dyslipidemia on T2DM can lead pancreatic $\beta$ cell dysfunction. Objective: This study aimed to determine the correlation between lipid profiles (triglyceride, total cholesterol, LDL, and HDL) with pancreatic $\beta$ cell function (HOMA- $\beta$ ) in patients with T2DM. Methods: This research method is a crosssectional study of 50 patients with T2DM at Community Health Center (45-65 years old). Lipid profiles level were analized by glycerol-3-phosphate-oxidase (GPO) PAP method (Genius) and insulin level was analized by using ELISA. $\beta$ cell function is measured using HOMA- $\beta$. Pearson Correlation test was used to assess the correlation between lipid profiles with HOMA- $\beta$ ( $p$ value $<0.05$ ) Results: This study showed no significant relationship between triglyceride and HOMA- $\beta(p=0,430)$, total cholesterol with HOMA- $\beta$ ( $p=0,717)$, LDL with HOMA- $\beta(p=0,633)$, HDL with HOMA- $\beta(p=0,754)$. There is no significant relationship between lipid profiles (triglyceride, total cholesterol, LDL, and HDL) and $\beta$ cell function. For further research, it is recommended to examine other factors such as food intake by taking into account the drugs consumed.
\end{abstract}

Keywords: HOMA- $\beta$, lipid profiles, type 2 diabetes

\section{INTRODUCTION}

The prevalence of Diabetes Mellitus (DM) increase in Indonesia and in world. International Diabetes Federation (IDF) showed that 415 million people were diagnosed with DM and it will increase to 642 million (55\%) in the 2040. Indonesia ranked 7 most diabetic population in the world (around 10 million). The national prevalence diabetic people in Indonesia were 6.8\% [1]. All of DM patients in Indonesia , 80-90\% are Type 2 Diabetes Mellitus (T2DM). T2DM is a metabolic syndrome characterized by high blood glucose caused by insufficient insulin secretion, insulin resistance, or both. It is also followed by high lipid profile [2][3][4].

Lipid abnormalities are common in people with T2DM. Type 2 diabetes mellitus are usually characterized by high total cholesterol (T-Chol), high triglycerides (Tg), low high density lipoprotein cholesterol (HDL-C) and possibly by increased levels of small dense LDL particles. Low density lipoprotein cholesterol (LDL-C) levels may be moderately increased or normal [5]. Study in 2016 found that $74.11 \%$ of T2DM patients had hyperlipidemia and $25.89 \%$ had normal (of $200 \mathrm{~T} 2 \mathrm{DM}$ patients). The pattern of lipid abnormalities observed was high triglyceride in 46 (31.08\%) patients, high LDL in $25(16.89 \%)$, low HDL in $14(09.45 \%)$, high cholesterol in $24(16.21 \%)$ and combined hyperlipidemia in $39(26.35 \%)$ diabetic patients [6]. Among of various factorsthat play a role, dislipidemia plays an important role in the pathogenesis of pancreatic $\beta$ cell dysfunction [4].

Cholesterol homeostasis is fundamental in terms in process insulin secretion in pancreas $\beta$ cells. Insulin granules are the major sites of intracellular cholesterol accumulation in $\beta$ cells. Excess cholesterol changes insulin granule properties and alters the distribution of insulin granule membrane proteins leading defect for insulin granule exocytosis. Excess cholesterol also caused reduced glucose-stimulated insulin secretion from $\beta$ cells. Excess cholesterol inhibits granule membrane remodeling, it is unlikely that such a defect in granule maturation fully accounts for the broad effect of cholesterol addition on a large portion of the granule population. The increased granule size results 
primarily from direct alterations of the granule membrane induced by cholesterol addition. High cholesterol levels will cause an enlargement of insulin granules up to $80 \%$. In addition, excess cholesterol will also cause interference or damage to the maturation process of insulin granules [7]. In addition, accumulation of excessive cholesterol in $\beta$ cell pancreas is leading lipotoxicity which reduces insulin secretion, causing $\beta$ cell dysfunction and reduce $\beta$ cells pancreas mass [8]. Some studies determined that diabetes or prediabetes individuals have higher total cholesterol values than healthy individuals with normal glucose tolerance [9].

Beside cholesterol, high levels of triglyceride was found associated with pancreatic $\beta$ cells damage. Hypertriglyceridemia resulted in significant triglyceride stores in the islets, which subsequently inhibited glucoseinduced insulin secretion, at least in part, via reduced glucokinase activity in the islets [10]. High triglyceride (TG) were independent risk factors of $\beta$ cell dysfunction in newly diagnosed T2DM [11].

Recent study have examined that there is relationships between hyperlipidemia and $\beta$ cell function in patients newly diagnosed diabetes with hyperlipidemia and without hyperlipidemia [11]. Increasing total cholesterol and LDL$C$ cause $\beta$ cell function worse. Some studies show that higher LDL-C is high and lower HDL-C as an independent risk factor for $\beta$ cell dysfunction. also reported that high LDL values induced $\beta$ cell apoptosis. Meanwhile, high HDL stimulates insulin secretion as well inhibits $\beta$ cell apoptosis [8],[9],[12]. Low level of HDL-c is associated with an improved $\beta$-cell function in Chinese patients with newly diagnosed [13].

Although several studies have documented the effects dyslipidemia against $\beta$ cell function in the subject hyperglycemia, $\beta$ and cell function relationships dyslipidemia needs to be clarified. Some studies also reported that high LDL values induce $\beta$ cell apoptosis [9], [14]. While HDL stimulates insulin secretion as well inhibits $\beta$ cell apoptosis but cell $\beta$ function decreases with increasing LDL value.This findings are accordance with study that reported that $\beta$ cell function decreases in individuals with high LDL [9]. This study shows that LDL inhibits insulin secretion that is stimulated glucose and $\beta$ cell proliferation. Pancreatic $\beta$ cell function has a relationship significant negative with total cholesterol and LDL. There is no significant relationship between the function of $\beta$ cells of the pancreas with HDL and triglycerides [15].

In rural Bangladeshi population, the prevalences of dyslipidemia, especially low HDL-C and high Tg were found to be alarmingly high. The proportion of subjects with unfavorable lipid profiles increased with degree of glucose intolerance. High levels of $\mathrm{Tg}$ in combination with low levels of HDL-C showed the strongest association with T2DM and prediabetes [5].

Pancreatic $\beta$ cell dysfunction and resistance peripheral insulin are characteristics of T2DM markers. Interference with $\beta$ cell function leads to which decrease in insulin secretion response to glucose is marker for diabetes. Type 2 diabetes mellitus (T2DM) is characterized by decreased beta-cell function on the background of increased insulin resistance [16].

\section{METHOD}

\section{Subject}

The study design used cross sectional research with the participants of 50 outpatients with T2DM. All subjects were outpatients with T2DM in Yogyakarta Indonesia based on their inclusion criteria such as T2DM outpatients (fasting blood glucose between $80-350 \mathrm{mg} / \mathrm{dL}$ ), agreed and signed the informed consent, able to communicate, no kidney or cardiovascular disease complication, 35-65 years old. Sampling was determined by convenience random sampling technique. After recruitment, data collected included age, sex, marital status, religion, ethnicity, number of families, diet taken, supplement consumption, herbal or tea consumption, history of illness in the last 1-3 months, family history, type and dose of drugs consumed, smoking status, presence of infection and presence abscesses as well as long-standing DM. These data are collected by interviews with patients conducted using questionnaires.

\section{Study design}

The design of this study uses a cross-sectional study that to find correlation between lipid profiles with HOMA- $\beta$.

\section{Measurement of nutritional status}

Nutritional status is measured using body mass index (BMI). Nutritional status is determined by anthropometric measurements including measurements of body weight $(\mathrm{kg})$ and height $(\mathrm{cm})$ in units of $\mathrm{kg} / \mathrm{m} 2$ by using the formula = weight $(\mathrm{kg})$

\section{Height squared $\left(\mathrm{m}^{2}\right)$}

Weight was measured with minimum clothing using digital balance (Camry brand) $200 \mathrm{~kg}$ capacity with $0.1 \mathrm{~kg}$ sensitivity. Height was measured by microtoice with a length of $200 \mathrm{~cm}$ with $0.1 \mathrm{~cm}$ sensitivity without shoes in an erect standing position

\section{Blood pressure measurement}

Blood pressure values are average for three times of the systolic and diastolic blood pressure measurements. Blood pressure values are measured using a stethoscope and mercury sphygmomanometer (Omron brand).

\section{Preparation of blood samples}

Blood samples are used to obtain serum for examination of lipid profile levels, fasting blood glucose levels and fasting insulin levels. Before blood is drawn, patients are asked to fast for 8-10 hours to subsequently be taken blood samples. Fasting is a condition of no calorie intake but drinking water is permitted. Blood is drawn through the cubital veins which 
presented as mean \pm standard deviation (SD). Normality data distribution is tested by One-Sample

was done at the collection site. Each venous blood sample taken was collected in a tube and then centrifuged at a rate of 2-3 x $103 \mathrm{rpm}$ for 15 minutes to obtain serum. The serum is pipetted using a micropipette and put in an ependoff tube and labeled according to the randomization number and then stored in the refrigerator at $-40^{\circ} \mathrm{C}$ to $-80 \mathrm{oC}$ until an examination is carried out for checking lipid profile levels, fasting blood glucose levels and fasting insulin levels. Blood samples are taken by laboratory staff.

\section{Examination of lipid profiles, fasting blood glucose and fasting insulin levels}

Serum samples of all patients were analyzed for lipid profile, fasting serum glucose and fasting insulin levels. Lipid profiles such as total cholesterol and HDL (High Density Lipoprotein) cholesterol blood levels were measured using the cholesterol oxidase-p-amino phenazone method (CHOD-PAP method). Triglyceride levels were measured using glycerol-3-phosphate-oxidase (GPO) PAP method. Total cholesterol, HDL cholesterol and triglycerides were analyzed by the Diasys kit (Diasys diagnostic system GmbH Alte Strasse 965558 Holzheim Germany). LDL levels are calculated indirectly from total cholesterol concentration (ChC), HDL cholesterol concentration (HDLC) and triglyceride concentration ( $\mathrm{TgC}$ ) were measured by using the formula of $\mathrm{LDL}=$ Total ChC$(\mathrm{TgC} / 5+\mathrm{HDL})$ in $\mathrm{mg} / \mathrm{dL}$ units. Fasting blood glucose levels are measured using the glucose oxidase-para amino phenazone (GOD-PAP) method. The principle of measurement is the enzymatic process of glucose oxidation by the glucose oxidase enzyme producing glucuronic acid \& $\mathrm{H} 2 \mathrm{O} 2$, measured using the glucose oxidase-para amino phenazone (GOD-PAP) method in $\mathrm{mg} / \mathrm{dL}$ units by the Diasys kit (Diasys diagnostic system GmbH Alte Strasse 9 65558 Holzheim Germany). Insulin levels were measured using Microparticle Immunoassay (ELISA methode) with IU/ $\mathrm{mL}$ units. Fasting insulin levels were analyzed by the insulin ELISA kit (The Calbiotech A life science company).

\section{Measurement of pancreatic $\beta$ cell function}

Pancreatic $\beta$ cell damage was determined using HOMA- $\beta$ index by measuring fasting glucose levels $(\mathrm{mg} / \mathrm{dL})$ and fasting insulin levels $(\mu \mathrm{IU} / \mathrm{mL})$. Pancreatic $\beta$ cell function status was assessed using homeostasis beta assessment model for knowing the level of beta cell function $(\mathrm{b} \%)$ by the formula: (360x fasting blood glucose $(\mathrm{mg} / \mathrm{dL}) /$ (fasting blood insulin ( $\mu \mathrm{IU} / \mathrm{mL})-63)$ manually.

\section{Statistical Analysis}

All data were analyzed using software of SPSS 20.0 programme. The result of descriptive variables including antropometric data (weight, height), systolic blood pressure, diastolic blood pressure, blood lipid profiles markers level, fasting glucose marker level, and fasting insulin level were
Kolmogorov-Smirnov Test. Correlation between lipid profiles and HOMA- $\beta$ are measured using Pearson Correlation Test. P-value less than 0.05 was considered statistically significant.

\section{Ethical considerations}

The study protocol was explained in detail to all participants. All intervention were executed after the respondents agreed and signed the informed consent. The study protocol was approved by Ethics Committee at Faculty of Medical Science Public Health and Nursing Gajah Mada University (Ethical clearance number KE/FK/00995/2018). At in the beginning of the study after explaining all steps of the study for patients a written consent was obtained from all participants and they were assured that their information will be kept totally secret. All of them were free to leave the study whenever they want. Respondents agreed and signed the informed consent The most of the samples were characterized by married, Muslim, Javanese ethnicity and had more than $\geq 2$ family members. All of them, $100 \%$ consumed lowering glucose drug with additionally blood pressure medicaton (44\%) and hyperlipidemia drugs. Most of the samples were nonsmokers and had long-standing diabetes (more than 1 year). We don't found any abscess and only $4 \%$ of sample had an infection. Table 2 gives description of clinical characteristic and laboratory examination of samples.

\section{RESULTS AND DISCUSSION}

Participants in this study are 50 outpatients T2DM and most of them are female $(74 \%)$. The average age of the samples is 55.64 years old. Table 1 shows characteristic subject in this research for detail.

Table 1. Characteristic Subject

\begin{tabular}{|c|c|c|}
\hline Variables & $\mathrm{N}=50$ & $\%$ \\
\hline \multicolumn{3}{|l|}{ Sex } \\
\hline a. Female & 37 & 74 \\
\hline b. Male & 13 & 26 \\
\hline \multicolumn{3}{|l|}{ Marital status } \\
\hline $\begin{array}{ll}\text { a. } & \text { Married }\end{array}$ & 45 & 90 \\
\hline b. Widower & 5 & 10 \\
\hline \multicolumn{3}{|l|}{ Religion } \\
\hline a. Islam & 43 & 86 \\
\hline b. $\quad$ Catholic & 5 & 10 \\
\hline $\begin{array}{ll}\text { c. } & \text { Christian }\end{array}$ & 2 & 4 \\
\hline
\end{tabular}


hyperlipidemia drugs. Most of the samples were nonsmokers and had long-standing diabetes (more than 1 year). We don't found any abscess and only $4 \%$ of sample had an infection. Table 2 gives description of clinical characteristic and laboratory examination of samples.

Table 2. Clinical Characteristic and Laboratory Test

\begin{tabular}{|l|c|c|c|c|}
\hline \multicolumn{1}{|c|}{ Variable } & Min & Max & Mean \pm SD & p-value*) \\
\hline Age (year) & 41 & 64 & $55.64 \pm 5.54$ & 0.501 \\
\hline Weight (kg) & 45.20 & 110.80 & $64.15 \pm 12.07$ & 0.415 \\
\hline Height (cm) & 136.10 & 167.60 & $153.55 \pm 6.91$ & 0.932 \\
\hline $\begin{array}{l}\text { Body mass index } \\
\text { (kg/m2) }\end{array}$ & 19.78 & 39.44 & $27.12 \pm 4.13$ & 0.796 \\
\hline $\begin{array}{l}\text { Systolic blood pressure } \\
\text { (mmHg) }\end{array}$ & 103.00 & 188.00 & $145.10+20.21$ & 0.984 \\
\hline $\begin{array}{l}\text { Diastolic blood pressure } \\
\text { (mmHg) }\end{array}$ & 66.00 & 100.00 & $80.08 \pm 8.93$ & 0.350 \\
\hline $\begin{array}{l}\text { Fasting blood glucose } \\
\text { (mg/dL) }\end{array}$ & 88.00 & 304.00 & $148.66 \pm 46.70$ & 0.591 \\
\hline $\begin{array}{l}\text { Fasting blood insulin } \\
(\mu \mathrm{IU} / \mathrm{dL})\end{array}$ & 1.07 & 60.45 & $12.27 \pm 10.58$ & 0.027 \\
\hline $\begin{array}{l}\text { Beta cell function } \\
\text { (HOMA- } \beta \text { ) \% }\end{array}$ & 4.95 & 255.80 & $67.35 \pm 5.57$ & 0.172 \\
\hline $\begin{array}{l}\text { Triglyceride (mg/dL) } \\
\text { Total cholesterol } \\
\text { (mg/dL) }\end{array}$ & 63.00 & 621.00 & $212.94 \pm 129.4$ & 0.071 \\
\hline $\begin{array}{l}\text { Low density lipoprotein } \\
(\mathrm{mg} / \mathrm{dL})\end{array}$ & 35.00 & 198.00 & $117.45 \pm 34.15$ & 0.426 \\
\hline $\begin{array}{l}\text { High density lipoprotein } \\
\text { (mg/dL) }\end{array}$ & 29.00 & 101.00 & $47.58 \pm 12.04$ & 0.602 \\
\hline
\end{tabular}

*) One sample Kolmogorov-Smirnov Test

The ability of pancreatic beta cells to produce insulin is shown by the value of HOMA- $\beta$ which is found in most of the HOMA- $\beta$ values in low category. This shows that pancreatic beta cells in most T2DM patients have been damaged. Although statistically it does not show a significant relationship between lipid profiles with HOMA$\beta(\mathrm{p} \geq 0.05)$ as shown in Table 3.

Table 3. Correlation Lipid Profiles With HOMA- $\beta$

\begin{tabular}{|l|c|}
\hline & p-value*) \\
\hline Triglyceride (mg/dL) & 0,430 \\
\hline Total cholesterol (mg/dL) & 0,717 \\
\hline Low density lipoprotein (mg/dL) & 0,633 \\
\hline High density lipoprotein (mg/dL) & 0,754 \\
\hline
\end{tabular}

*) Pearson Correlation Test 
The distribution of HOMA- $\beta$ values based on lipid profiles are illustrated in table below. Low HOMA- $\beta$ values are found in DMT2 patients with normal TG, LDL-c, and HDL$\mathrm{C}$ levels also above normal cholesterol levels (moderate and high levels).

Table 4. Distribution of HOMA- $\beta$ based On Triglycerides Level

\begin{tabular}{|l|c|c|c|c|c|c|}
\hline \multirow{3}{*}{ Triglyceride } & \multicolumn{6}{|c|}{ HOMA- $\beta$} \\
\cline { 2 - 7 } & \multicolumn{2}{|c|}{ Normal } & \multicolumn{2}{c|}{ Low } & \multicolumn{2}{c|}{ Total } \\
\cline { 2 - 7 } & $\mathrm{n}$ & $\%$ & $\mathrm{n}$ & $\%$ & $\mathrm{n}$ & $\%$ \\
\hline Normal & 4 & 25 & 12 & $\mathbf{7 5}$ & 16 & 100 \\
\hline Above normal & 13 & 38.2 & 21 & 61.8 & 34 & 100 \\
\hline
\end{tabular}

Diabetes mellitus type 2 patients with normal and not normal (moderate and high) TG levels have low HOMA- $\beta$ values but however, it is more common in T2DM patients with normal TG values.

Table 5. Distribution of HOMA- $\beta$ Based on Total Cholesterol Level

\begin{tabular}{|l|c|c|c|c|c|c|}
\hline \multirow{2}{*}{ Total cholesterol } & \multicolumn{6}{|c|}{ HOMA- $\beta$} \\
\cline { 2 - 7 } & \multicolumn{2}{|c|}{ Normal } & \multicolumn{2}{|c|}{ Low } & \multicolumn{2}{c|}{ Total } \\
\cline { 2 - 7 } & $\mathrm{n}$ & $\%$ & $\mathrm{n}$ & $\%$ & $\mathrm{n}$ & $\%$ \\
\hline Normal & 10 & 41.7 & 14 & 58.3 & 24 & 100 \\
\hline Above normal & 7 & 36.8 & 19 & $\mathbf{7 3 . 2}$ & 26 & 100 \\
\hline
\end{tabular}

Low HOMA- $\beta$ values are often found in patients with T2DM with cholesterol levels above normal (moderate and high).

Table 6. Distribution of HOMA- $\beta$ Based on LDL-C Level

\begin{tabular}{|l|c|c|c|c|c|c|}
\hline \multirow{2}{*}{$\begin{array}{l}\text { Low density } \\
\text { lipoprotein }\end{array}$} & \multicolumn{2}{|c|}{ Normal } & \multicolumn{2}{|c|}{ Low } & \multicolumn{2}{c|}{ Total } \\
\cline { 2 - 7 } & $\mathrm{n}$ & $\%$ & $\mathrm{n}$ & $\%$ & $\mathrm{n}$ & $\%$ \\
\hline Normal & 4 & 30,8 & 9 & $\mathbf{6 9 , 2}$ & 13 & 100 \\
\hline Above normal & 13 & 35,1 & 24 & 64,9 & 37 & 100 \\
\hline
\end{tabular}

DMT2 patients with normal LDL levels had 69,.2 \% low HOMA- $\beta$ values. Likewise, distribution of a low HOMA- $\beta$ values were found in DMT2 patients with HOMA- $\beta$ values is above normal (moderate and high LDL) too.

Table 7. Distribution of HOMA- $\beta$ Based on HDL-C Level

\begin{tabular}{|c|c|c|c|c|c|c|}
\hline \multirow{3}{*}{$\begin{array}{l}\text { High density } \\
\text { lipoprotein }\end{array}$} & \multicolumn{6}{|c|}{ HOMA- $\beta$} \\
\hline & \multicolumn{2}{|c|}{ Normal } & \multicolumn{2}{|c|}{ Low } & \multicolumn{2}{|c|}{ Total } \\
\hline & $\mathrm{n}$ & $\%$ & $\mathrm{n}$ & $\%$ & $\mathrm{n}$ & $\%$ \\
\hline Normal & 7 & 30.5 & 16 & 69.5 & 23 & 100 \\
\hline Above normal & 10 & 37 & 17 & 63 & 27 & 100 \\
\hline
\end{tabular}

The distribution of low HOMA- $\beta$ were also commonly found in DMT2 patients with normal HDL levels. It is well established that cholesterol homeostasis is fundamental for appropriate insulin secretory function of $\beta$ cells [17], as excessive cholesterol accumulation in $\beta$ cells may cause lipotoxicity and reduce insulin secretion, causing $\beta$ cell dysfunction and decreased $\beta$ cell mass. This study shows that there is no significant relationship between lipid profiles and HOMA- $\beta(\mathrm{p} \geq 0.05)$ but we found a tendency that low HOMA- $\beta$ values are often found in patients with T2DM with cholesterol levels above normal (moderate and high). This study also found that the number of samples with low HOMA- $\beta$ values was greater than normal HOMA$\beta$. This might be due to the fact that some of the samples were old (average age 55.64 years old). This is in line with research conducted by Fumiaki et al. (2013) that describe 1 in 4 cases of DM in older adults can be preceded primarily by $\beta$-cell dysfunction and that their risk can be missed by relying on conventional risk factors such as adiposity and atherogenic dyslipidemia. Among older adults, impaired $\beta$ cell function is more common than younger adults [18]. This is in accordance with research conducted in China (2016) whereas in a Chinese population with different levels of glucose tolerance, TG/HDL-C and TG could be the predictors of insulin resistance (IR). The lipid ratios could not be reliable makers of $\beta$ cell function in the population [19]. Another studies that are not in line with this research show that TG and HDL-C correlate with insulin resistance. Triglyseride and total cholesterol correlates negatively with $\beta$-response cells to insulin resistance in non-diabetic individuals [20]. Dyslipidemia is challenging with pancreatic $\beta$ dysfunction cells in subjects with NGT and this is especially seen in people with elevated TC and LDL-C levels, especially men [9].

Beta-cell function and insulin sensitivity were significantly improved through a low-fat plant-based diet in overweight adults [21].Dietary glycemic load, glycemic index, and refined grains intakes are associated with reduced $\beta$-cell function, and the quality of dietary carbohydrates may be relevant for maintaining $\beta$-cell function among individuals [22]. Besides food intake factor, consumption of antihyperlipidemia drugs is very influential on beta cell damage. Metformin and Acarbose can improvement of pancreatic $\beta$-cell function and insulin resistance in Chinese patients with newly diagnosed T2DM [13]. Recent research that conducted between June and September 2007, was designed to provide reliable data on the relationship between $\beta$ cell function and lipid profiles in Chinese individuals without prior history of diabetes or prediabetes. Dyslipidemia is associated with dysfunction of pancreatic $\beta$ cells in subjects with NGT and this is particularly evident in people with elevated TC and LDL-C levels, especially males [9].

\section{CONCLUSION}

There is no significant relationship between lipid profiles (triglyceride, total cholesterol, LDL, and HDL) with $\beta$ cell function (HOMA- $\beta$ ). For further research, it is recommended to examine other factors such as food intake by taking into account the drugs consumed

\section{REFERENCES}

[1] Badan Penelitian dan Pengembangan Kesehatan. (2013). Riset Kesehatan Dasar (RISKESDAS). Laporan Nasional 2013, 1-384. https://doi.org/1 Desember 2013 
[2] American Diabetes Association. (2018). Standards of Medical Care In Diabetes. The Journal of Clinical and Applied Research and Educationon, 41 (January). https://doi.org/https://doi.org/10.2337/dc18Sint01

[3] Siddiqui, A. A., Siddiqui, S. A., Ahmad, S., Siddiqui, S., Ahsan, I., \& Sahu, K. (2013). Diabetes: Mechanism, pathophysiology and management-A review. International Journal of Drug Development and Research, 5(2), 1-23. https://doi.org/10.2337/dc11-S011

[4] Perkumpulan Endokrinologi Indonesia. (2011). Konsensus Pengelolaan Dan Pencegahan Diabetes Melitus Tipe 2 Di Indonesia. Jakarta: PB. PERKENI

[5] Bhowmik, B., Siddiquee, T., Mujumder, A., Afsana, F., Ahmed, T., Mdala, I. A.,Omsland, T. K. (2018). Serum Lipid Profile and Its Association with Diabetes and Prediabetes in a Rural Bangladeshi Population. International journal of environmental research and public health, 15(9), 1944. doi:10.3390/ijerph15091944

[6] Parashram, Rajole Mahendra, Lamlakar ,Ahire Sushil. (2016) Study of Lipid Profile in patients with Diabetes Mellitus. J Cont Med A Dent ,January-April 2016 Volume 4 Issue 1

[7] Bogan, Jonathan S., Xu, Yingke., Hao, Mingming. (2012).Cholesterol Accumulation Increases Insulin Granule Size and Impairs Membrane Trafficking. Traffic 2012;13:1466-148,John Wiley \& Sons A/S doi:10.1111/j.1600-0854.2012.01407.x

[8] Bardini G, Rotella CM, Giannini S. (2012). Dyslipidemia And Diabetes: Reciprocal Impact Of Impaired Lipid Metabolism And Beta-Cell Dysfunction On Micro- And Macrovascular Complications. The Review of Diabetic Studies.

[9] Zheng T, Gao Y, Tian H. (2012). Relationship Between Blood Lipid Profles And Pancreatic Islet Â Cell Function In Chinese Men And Women With Normal Glucose Tolerance: Across-Sectional Study. BMC Public Health;12:634

[10] Man ZW, Zhu M, Noma Y, Toide K, Sato T, Asahi Y, Hirashima T, Mori S, Kawano K, Mizuno A, Sano T, Shima K.(1997). Impaired Beta-Cell Function and Deposition Of Fat Droplets In The Pancreas As A Consequence Of Hypertriglyceridemia In OLETF Rat, A Model Of Spontaneous NIDDM. Diabetes. Nov;46(11):1718-24.
[11] Yuhang Ma, Yufan Wang, Qianfang Huang. (2014), "Impaired Cell Function in Chinese Newly Diagnosed Type 2 Diabetes Mellitus with Hyperlipidemia," Journal of Diabetes Research, vol. 2014, Article ID 493039, 6 pages, 2014. https://doi.org/10.1155/2014/493039.

[12] Beaudry JL, Riddell MC. (2012). Efects Of Glucocorticoids And Exercise On Pancreatic $\beta$-Cell Function And Diabetes Development. Diabetes Metab Res Rev; 28: 560-73.

[13] Yan Duan, Jia Liu, and Yuan Xu. (2018).Factors That Influence Pancreatic Beta Cell Function and Insulin Resistance in Newly Diagnosed Type 2 Diabetes Patients: A Sub-Analysis of the MARCH Trial. Diabetes Therapy, April 2018, Volume 9, Issue 2

[14] Roehrich ME, Mooser V, Lenain V, Herz J, Nimpf J, Azhar S. (2003). Insulin-Secreting Beta-Cell Dysfunction Induced By Human Lipoproteins. Biol Chem;278:18368-75.

[15] Zarmal, Farik., Syafril, Santi., Lindarto, Dharma. (2016). Hubungan Fungsi Sel $\beta$ Pankreas dengan Profl Lipid Individu dengan Toleransi Glukosa Normal. CDK243/ vol. 43 no. 8 halaman 567-570

[16] Garg M.K, Dutta M K, Mahalle N. (2011). Study Of Beta-Cell Function (By HOMA Model) In Metabolic Syndrome. Indian J Endocr Metab; 15, Suppl S1:44-9

[17] Hao M, Head WS, Gunawardana SC,.(2007).Direct Effect Of Cholesterol On Insulin Secretion: A Novel Mechanism For Pancreatic Beta-Cell Dysfunction. Diabetes. 56: 2328-2338. 10.2337/db070056.

[18] Fumiaki Imamura, Kenneth J. Mukamal, James B. Meigs, José A. Luchsinger, Joachim H. Ix, David S. Siscovick, Dariush Mozaffarian. (2013). Risk Factors for Type 2 Diabetes Mellitus Preceded by $\beta$-Cell Dysfunction, Insulin Resistance, or Both in Older Adults: The Cardiovascular Health Study, American Journal of Epidemiology, Volume 177, Issue 12, 15 June 2013, Pages 1418-1429, https://doi.org/10.1093/aje/kws440

[19] Meicen Zhou, Lixin Zhu, Xiangli Cui, Linbo Feng, Xuefeng Zhao, Shuli He, Fan Ping, Wei Li, Yuxiu Li. (2016).The Triglyceride To High-Density Lipoprotein Cholesterol (TG/HDL-C) Ratio As A Predictor Of Insulin Resistance But Not Of B Cell Function In A Chinese Population With Different Glucose Tolerance Status Lipids Health Dis. ; 15: 104. 
Published online 2016 Jun 7. doi: 10.1186/s12944-0160270-z

[20] Zheng S, Xu H, Zhou H, Ren X, Han T, Chen Y, et al. (2017) Associations Of Lipid Profiles With Insulin Resistance And B Cell Function In Adults With Normal Glucose Tolerance And Different Categories Of Impaired Glucose Regulation. PLoS ONE 12(2): e0172221.

https://doi.org/10.1371/journal.pone.0172221

[21] Kahleova, Hana., Tura, Andrea.,Hill Martin., Holubkov, Richard., Barnard, Neal D. (2018). PlantBased Dietary Intervention Improves Beta-Cell Function and Insulin Resistance in Overweight Adults: A 16Week Randomized Clinical Trial. Nutrients, 10, 189; doi:10.3390/nu10020189

[22] Sartorelli, Daniela Saes et al. (2009). Dietary Glycemic Load, Glycemic Index, And Refined Grains Intake Are Associated With Reduced B-Cell Function In Prediabetic Japanese Migrants. Arq Bras Endocrinol Metab [online]., vol.53, n.4 http://dx.doi.org/10.1590/S0004-27302009000400007. 